\title{
Exergy Analysis of Combined Cycle Power Plant: NTPC Dadri, India
}

\author{
A.K.Tiwari ${ }^{* 1}$, M.M. Hasan ${ }^{2}$, Mohd. Islam ${ }^{2}$ \\ ${ }^{1}$ ITS Engineering College, Greater Noida-201308, India. arvindtiwarirk@its.edu.in \\ ${ }^{2}$ F/o Engineering \& Technology, Jamia Millia Islamia, New Delhi-110025, India. \\ muzaffar_jmi@yahoo.co.in, mislam@jmi.ac.in
}

\begin{abstract}
Exergy analysis of the combined Brayton/Rankine power cycle of NTPC (National Thermal Power Corporation) Dadri India is presented. Theoretical exergy analysis is carried out for different components of Dadri combined cycle power plant which consists of a gas turbine unit, heat recovery steam generator without extra fuel consumption, and steam turbine unit. The results pinpoint that more exergy losses occurred in the gas turbine combustion chamber reaching $35 \%$ of the total exergy losses, while the exergy losses in other plant components are between $7 \%$ and $21 \%$ of the total exergy losses at $1400^{\circ} \mathrm{C}$ turbine inlet temperature and pressure ratio 10 . This paper also considered the effect of the pressure ratio, turbine inlet temperature, pressure drop in combustion chamber, and heat recovery steam generator on the exergy losses in the plant. There are clear effects in the exergy losses when changing pressure ratio and turbine inlet temperature.
\end{abstract}

Keywords: Gas turbine cycle; steam turbine cycle; combined cycle; pressure ratio; exergy losses.

\section{Introduction}

Energy conservation concept (or the first law of thermodynamics) does not give the detailed analysis of the losses in power plant components. It is necessary to pinpoint the exergy losses. Exergy analysis enables one to determine the maximum work that can be expected from energy device or process; this is possible because the second law expresses the quality of energy. The purpose of this work is to analyze the performance of a combined power plant according to the second law of thermodynamics using the exergy analysis.

Most recently Mansouri et al (2012) investigated the effect of HRSG (heat recovery steam generator) pressure levels on exergy efficiency of combined cycle power plants and show that increases in the number of pressure levels of the HRSG affect the exergy losses due to heat transfer in the HRSG and the exhaust of flue gas to the stack. The different configuration of combined cycle studied by Ibrahim et al (2011) that the simple gas turbine configuration is more suitable with regards to power output, but the regenerative gas turbine configuration has higher efficiency with effect to ambient temperature. The simple gas turbine configuration has higher power output with effect to the compression ratio, while the regenerative gas turbine configuration has higher efficiency with effect to lower compression ratio; therefore the variation of total power output is insignificant at lower compression ratio.

Sanjay (2011) investigated the effect of operating parameters on the rational efficiency and exergy destruction of combined cycle and showed that higher TIT and higher compressor pressure ratio is favorable on the performance of combined cycle. The development of medium size (50$120 \mathrm{MW}$ ) combined cycle power plants analyzed by the Franco (2011) in which the alternative design of combined cycle power plants with a supercritical HRSG was presented without efficiency increase. Regulagadda et al (2010) conducted a parametric study for the plant under various operating conditions, including different operating pressures, temperatures and flow rates, in order to determine the parameters that maximize plant performance. The exergy loss distribution indicates that boiler and turbine irreversibility yield the highest exergy losses in the power plant. The combined cycle system is optimized by Srinivas (2010) at a gas turbine inlet temperature of $1400^{\circ} \mathrm{C}$ due to the present available technology of modern gas turbine blade cooling systems and developed high performance, better conditions for compressor, HRSG sections, steam reheater and deaerator.

Aljundi (2009) presented the energy and exergy analysis of Al-Hussein power plant in Jordan where energy losses mainly occurred in the condenser and $134 \mathrm{MW}$ is lost to the environment while only $13 \mathrm{MW}$ was lost from the boiler system. Polyzakis et al (2008) described and compared the optimization of a combined cycle power plant of four different gas turbine cycles: simple cycle, intercooled cycle, reheated cycle and intercooled \& reheated cycle. The results show that the reheated gas turbine is the most desirable overall, mainly because of its high turbine exhaust gas temperature and resulting high thermal efficiency of the bottoming steam cycle.

Koch et al (2007) studied the application of an evolutionary algorithm to the minimization of the product cost of complex combined cycle power plants. A technique to reduce the irreversibility of the steam generator of the combined cycle was introduced by Bassily (2005). The effects of varying the inlet temperature of the gas turbine (TIT) and pinch points on the performance of all cycles were presented and discussed. The results indicated that the optimized combined cycle is up to $1 \%$ higher in efficiency than the reduced-irreversibility combined-cycle, which is $2-2.5 \%$ higher in efficiency than the regularly designed combined cycle when compared for the same values of TIT and pinch points. Bejan (2002) reviewed the concept of irreversibility, entropy generation, and exergy destruction. Examples illustrate the accounting for exergy flows and accumulation in closed systems, open systems, heat transfer 
processes and power, refrigeration plants. Wu (1999) described the use of intelligent computer software to obtain a sensitivity analysis for the combined cycle. Heppenstall (1998) described and compared several power generation cycles which have been developed to take advantage of the gas turbine's thermodynamic characteristics. Emphasis has been given to systems involving heat recovery from the gas turbine's exhaust and these include the combined, kalina, gas/gas recuperation, steam injection, evaporation and chemical recuperation cycles.

Nag and Raha (1995) evaluated the effects of pressure ratio and peak cycle temperature ratio of the gas cycle and the lower saturation pressure of the steam cycle on the overall performance of the combined plant. Here the working fluids work over a large temperature range, say from $1100^{\circ} \mathrm{C}$ to $550^{\circ} \mathrm{C}$ in the gas turbine and $550^{\circ} \mathrm{C}$ to the ambient temperature in the steam turbine, thus achieving an overall efficiency approaching 50\%. Horlock (1995), based on thermodynamic considerations, outlined more recent developments and future prospects of combined cycle power plants. Polyzakis (1995) carried out the firstlaw analysis of reheat industrial gas turbines used in a combined cycle and suggested that the use of reheat is a good alternative for combined cycle applications.

Cerri (1987) analyzed the combined gas/steam plant, without reheat, from the thermodynamic point of view. In his analysis, he found out the parameters that most influence efficiency, and further reported that combined cycles exhibit a good performance if suitably designed, but if the highest gas turbine temperatures are used, expensive fuel must be utilized. Wunsch (1985) claimed that the efficiencies of combined gas/steam plants were more influenced by the gas turbine parameters like maximum temperature and pressure ratio than by those for the steam cycle and also reported that the maximum combined cycle efficiency was reached when the gas turbine exhaust temperature is higher than the one corresponding to the maximum gas turbine efficiency. Czermak and Wunsch (1982) carried out the elementary thermodynamic analysis for a practicable Brown Boveri 125 MW combined gas/steam turbine power plant. The early development of the gas/steam turbine plant was described by Sieppel and Bereuter (1960).

The performance analysis based on the first law alone is inadequate. The more meaningful evaluation must include a second-law analysis. One reason that such an analysis has not gained much engineering use may be the additional complication of having to deal with the "combustion irreversibility", which introduced an added dimension to the analysis. Second-law analysis indicates the association of exergy destruction with combustion and heat transfer processes and allows a thermodynamic evaluation of energy conservation in thermal power cycles.

Although there is sufficient literature on combined power cycle, no systematic exergy analysis of combined gas/steam cycles has been reported. The objective of the present paper is to develop a systematic and improved second-law based thermodynamic methodology for the exergy analysis of combined gas/steam power plant. In the present work, effect of TIT and compressor pressure ratio on combined cycle performance has been attempted with data taken from NTPC dadri, India.

\section{System Description}

NTPC (National Thermal Power Corporation) was set up in the central sector in the 1975. Only PSU (Public Sector Unit) to achieve excellent rating in respect of MOU (Millions of Unit) targets signed with Government of India each year. NTPC Dadri station has also bagged ISO 14001 certification. Today NTPC contributes more than 3/5th of the total power generation in India. The schematic diagram of NTPC Dadri (Gas Unit) combined power cycle is shown in Figure 2. The gas turbine (Siemens AG, Germany, V 94.2, 131.3 MW, 2 No.) is shown as a topping plant, which forms the high temperature loop, whereas the steam plant (BHEL India, 146.5 MW, two cylinder condensing reaction, $2 \times 22$ no of stages HP) forms the low temperature loop. The connecting link between the two cycles is the heat recovery steam generator (BHEL Trichy, Vertical forced Circulation) working on the exhaust of the gas turbine. A gas turbine cycle consists of an air compressor (Siemens KWU, Type Multistage axial flow, .No. of stages16), a combustion chamber (Vertical Silo Type) and a gas turbine. The turbine's exhaust-gas goes to a heatrecovery steam generator to generate superheated steam. That steam is utilized in a standard steam power cycle, which consists of a turbine, a condenser (BHEL, Rectangular, SCD2-1200) and a pump (BHEL Hyderabad, Vertical Mixed Flow). Both the gas and steam turbines drive electric generators.

\section{Thermodynamic Analysis}

For thermodynamic analysis the T-s diagram (Figure 1) is concerned for the layout shown in Figure 2. The temperature of gases after leaving from gas turbine is given by

$T_{4}=T_{3}\left[\frac{1}{r_{p g}}\right]^{\frac{\left(\gamma_{g}-1\right) \eta_{G T}}{\gamma_{g}}} \quad$ where $r_{p g}=\frac{p_{3}}{p_{4}}$

The temperature of air after leaving the compressor

$T_{2}=T_{1}\left(r_{p c}\right)^{\frac{\left(\gamma_{a}-1\right)}{\gamma_{a} \eta_{c}}}$ where $r_{p c}=\frac{p_{2}}{p_{1}}$

The relation between gas turbine and compressor pressure ratio is

$r_{p g}=\left(1-\beta_{1}\right)\left(1-\beta_{2}\right) r_{p c}$

where $\beta_{1}$ and $\beta_{2}$ is percentage pressure drop in combustion chamber and HRSG respectively.

If the flow rate of combustion gas be $1 \mathrm{~kg} / \mathrm{s}$ and that of fuel is $\mathrm{f} \mathrm{kg} / \mathrm{s}$ then, the flow of air $=(1-\mathrm{f}) \mathrm{kg} / \mathrm{s}$ and flow of fuel is given by

$f=\frac{\left(c_{p g} T_{3}-c_{p a} T_{2}\right)}{\left(c v-c_{p a} T_{2}\right)}$

Air-fuel ratio $=\frac{1-f}{f}$ 


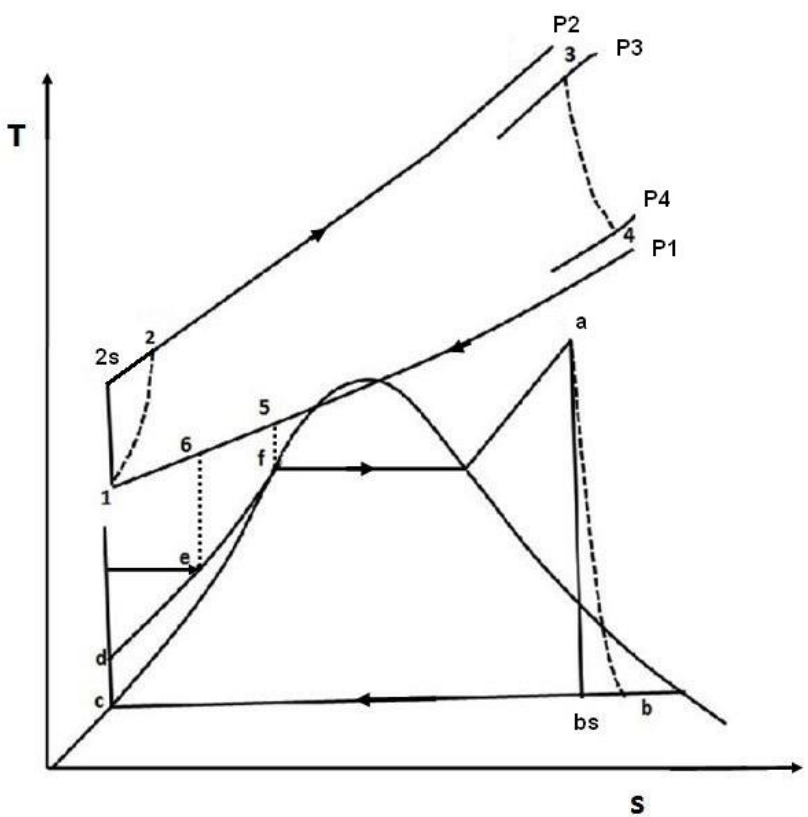

Figure 1. Temperature-Entropy diagram of Brayton/ Rankine combined cycle power plant.

Let the pinch point temperature difference $\left(T_{5}-T_{f}\right)$ be $25^{\circ} \mathrm{C}$ then

$\mathrm{T}_{\mathrm{f}}=\left(\mathrm{T}_{\text {Sat }}\right)_{60 \text { bar }}=275.64^{0} \mathrm{C}$ (from steam table)

and $\mathrm{T}_{5}=275.64+25=300.64^{\circ} \mathrm{C}$. Now from the steam table taking $h_{a}$ and $h_{f}$ and by energy balance mass flow rate of steam is

$w_{s}=\frac{c_{p g}\left(T_{4}-T_{5}\right)}{\left(h_{a}-h_{f}\right)}$

Let the total heat transfer in the HRSG yields the stack temperature $\mathrm{T}_{6}$. Then;
$T_{6}=T_{4}-\frac{w_{s}\left(h_{a}-h_{e}\right)}{c_{p g}}$

For dryness fraction equating entropy $s_{a}=s_{b s}$ : dryness fraction at $b_{\mathrm{s}}$ is

$x_{b s}=\frac{s_{a}-s_{f}}{s_{f g}}$

and enthalpy at $b_{\mathrm{s}}$ is

$h_{b s}=h_{f}+h_{f g} * x_{b s}$

The mass flow rate of gas in the cycle is

$m_{g}=\frac{m_{s}}{w_{s}}$

The mass flow rate of air in compressor is

$m_{a}=(1-f) m_{g}$

The mass flow rate of fuel in combustion chamber is

$m_{f}=f * m_{g}$

\section{Exergy Destruction in Different Components}

Compressor: The exergy loss due to irreversibility in compressor is given by

$I_{c}=m_{a} T_{o}\left(s_{2}-s_{1}\right)$

where

$s_{2}-s_{1}=C_{p a} \ln \frac{T_{2}}{T_{1}}-R_{a} \ln \frac{P_{2}}{P_{1}}$ and $R_{a}=C_{p a} \frac{(\gamma-1)}{\gamma}$

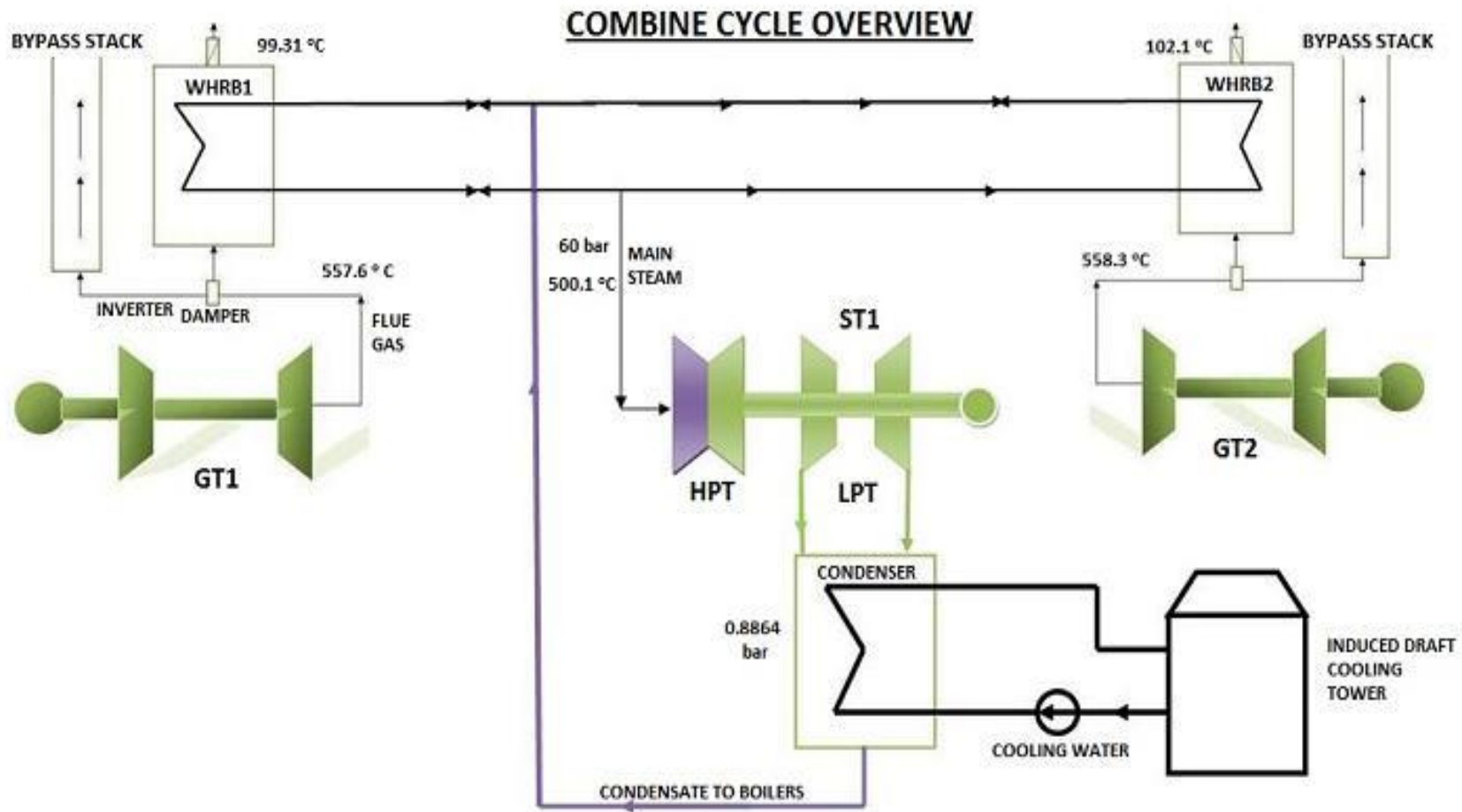

Figure 2. Schematic diagram of combined cycle power plant (NTPC-Dadri, Gas Unit). 
Combustor: The exergy loss due to irreversibility in combustor is given by

$$
\dot{I}_{c o m b}=T_{0}\left[\left(\dot{S}_{P}\right)_{3}-\left(\dot{S}_{R}\right)_{2}\right]
$$

where $\left(\dot{S}_{R}\right)_{2}=\left(\dot{S}_{A}\right)_{2}+\left(\dot{S}_{F}\right)_{0}$ and the subscripts P, R, A and $\mathrm{F}$ represent products, reactants, air and fuel respectively. Therefore,

$$
\dot{I}_{c o m b}=T_{0}\left[\begin{array}{l}
\left(\dot{S}_{p}\right)_{3}-\left(\dot{S}_{P}\right)_{0}+\left(\dot{S}_{P}\right)_{0} \\
-\left\{\left(\dot{S}_{A}\right)_{2}-\left(\dot{S}_{A}\right)_{0}+\left(\dot{S}_{F}\right)_{0}+\left(\dot{S}_{A}\right)_{0}\right\}
\end{array}\right]
$$

Now $\Delta \dot{S}_{0}=\left(\dot{S}_{P}\right)_{0}-\left[\left(\dot{S}_{F}\right)_{0}+\left(\dot{S}_{A}\right)_{0}\right]$ so

$$
\begin{aligned}
\dot{I}_{c o m b}=T_{0}\left[\begin{array}{l}
\left\{\left(\dot{S}_{p}\right)_{3}-\left(\dot{S}_{P}\right)_{0}\right\} \\
+\left\{\left(\dot{S}_{A}\right)_{2}-\left(\dot{S}_{A}\right)_{0}\right\}+\Delta \dot{S}_{0}
\end{array}\right] \\
=T_{0}\left[\begin{array}{l}
\left(\dot{m}_{g} C_{p g} \ln \frac{T_{3}}{T_{0}}-m_{g} R_{g} \ln \frac{P_{3}}{P_{0}}\right) \\
-\left(\dot{m}_{a} C_{p a} \ln \frac{T_{2}}{T_{1}}-m_{a} R_{a} \ln \frac{P_{2}}{P_{1}}\right)+\Delta \dot{S}_{0}
\end{array}\right]
\end{aligned}
$$

Gas Turbine: The exergy loss due to irreversibility in gas turbine is given by

$$
I_{G T}=m_{g} T_{0}\left(s_{4}-s_{3}\right)
$$

where $\left(s_{4}-s_{3}\right)=C_{p g} \ln \frac{T_{4}}{T_{3}}-R_{g} \ln \frac{P_{4}}{P_{3}}$ and

$R_{g}=C_{p g} \frac{(\gamma-1)}{\gamma}$

HRSG: The exergy loss due to irreversibility in heat recovery steam generator is given by

$$
\dot{I}_{h r s g}=T_{0} \Delta \dot{S}_{0}=T_{0}\left[\dot{m}_{s}\left(s_{a}-s_{e}\right)+\dot{m}_{g}\left(s_{6}-s_{4}\right)\right]
$$

where $s_{6}-s_{4}=C_{p g} \ln \frac{T_{6}}{T_{4}}-R_{g} \ln \frac{P_{6}}{P_{4}}$

Steam Turbine: The exergy loss due to irreversibility in steam turbine is given by

$$
\dot{I}_{S T}=\dot{m}_{s}\left(s_{b}-s_{a}\right) T_{0}
$$

Since isentropic efficiency of ST is

$\eta_{S T}=\frac{h_{a}-h_{b}}{h_{a}-h_{b s}}$

(for calculating $\mathrm{h}_{\mathrm{b}}$ ) and $h_{b}=h_{f}+x_{b} h_{f g}$

(for calculating $\mathrm{x}_{\mathrm{b}}$ ) so $s_{b}=s_{f}+x_{b} s_{f g}$

Exhaust Loss: The exergy loss due to irreversibility in exhaust is given by

$$
I_{\text {exh }}=\int_{T_{6}}^{T_{0}}\left(1-\frac{T_{0}}{T}\right) d Q=m_{g} C_{p g}\left[\left(T_{6}-T_{0}\right)-T_{0} \ln \frac{T_{6}}{T_{0}}\right]
$$

The Carnot efficiency is

$\eta_{\text {carnot }}=\left(1-\frac{T_{0}}{T_{3}}\right)$

The energy input to the combustion chamber is

$$
E=m_{f} * c v
$$

The exergy input to the combustion chamber is

$$
E x=E^{*} \eta_{\text {carnot }}
$$

Entropy change is

$$
\Delta \dot{S}_{0}=E x-E
$$

Total exergy destruction becomes

$$
I_{\text {Total }}=I_{C}+I_{c o m b}+I_{G T}+I_{h r s g}+I_{S T}+I_{e x h}
$$

\section{Results and Discussion}

Based upon the methodology developed and the equations derived here, the exergy loss due to irreversibility in different components of gas/steam combined power cycle is shown here graphically. For the result we made the assumptions given in Annexure-I.

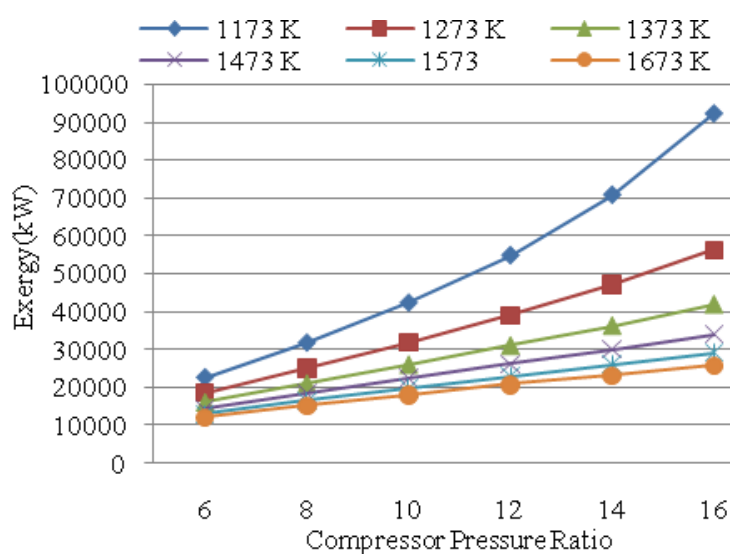

Figure 3. Graph of exergy losses in compressor vs $r_{p c}$ at different TIT.

Figure 3 shows the variation of exergy loss in compressor with variation in compressor pressure ratio and turbine inlet temperature. There is clear effect of compressor pressure ratio and turbine inlet temperature on exergy loss in compressor. At low turbine inlet temperature $\left(900^{\circ} \mathrm{C}\right)$ the exergy loss in the compressor is higher and as the turbine inlet temperature increases $\left(1400^{\circ} \mathrm{C}\right)$, the exergy loss is minimizing rapidly. There is similar pattern in exergy loss can be seen at temperature 1000 to $1400^{\circ} \mathrm{C}$ but at low turbine inlet temperature, the pattern is slightly different. At any particular turbine inlet temperature as the compressor pressure ratio increases the exergy loss increases. The behavior of curve is linear from 1100 to $1400^{\circ} \mathrm{C}$ and increases slowly rather than at 900 to $1000^{\circ} \mathrm{C}$. 


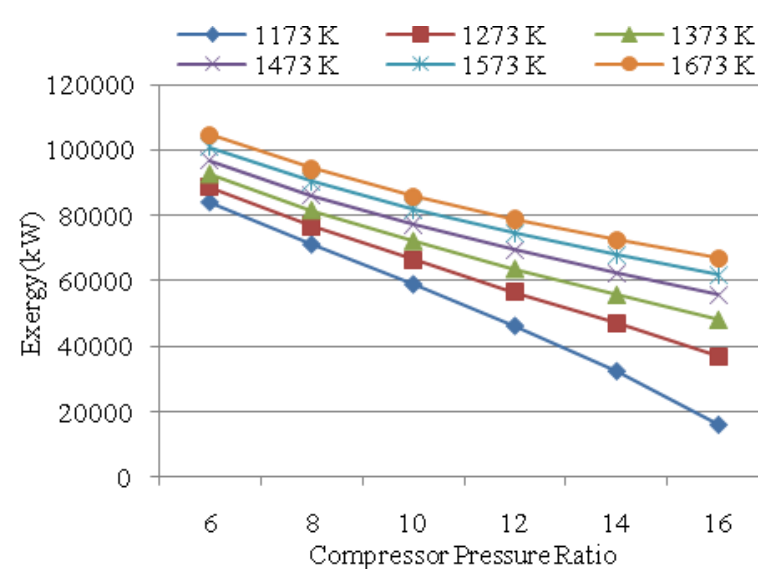

Figure 4. Graph of exergy loss in combustion chamber vs $r_{p c}$ at different TIT.

Figure 4 shows the variation of exergy loss in combustion chamber with variation in compressor pressure ratio and turbine inlet temperature. At low turbine inlet temperature $\left(900^{\circ} \mathrm{C}\right)$ the exergy loss in the combustion chamber is lower and as the turbine inlet temperature $\left(1400^{\circ} \mathrm{C}\right)$ increases, the exergy loss is increasing rapidly. There is similar behavior in exergy loss can be seen at temperature 1000 to $1400^{\circ} \mathrm{C}$ but at low turbine inlet temperature, the behavior is slightly different. At any particular turbine inlet temperature as the compressor pressure ratio increases the exergy loss decreases. In combustion chamber $35 \%$ to $50 \%$ of exergy loss is calculated.

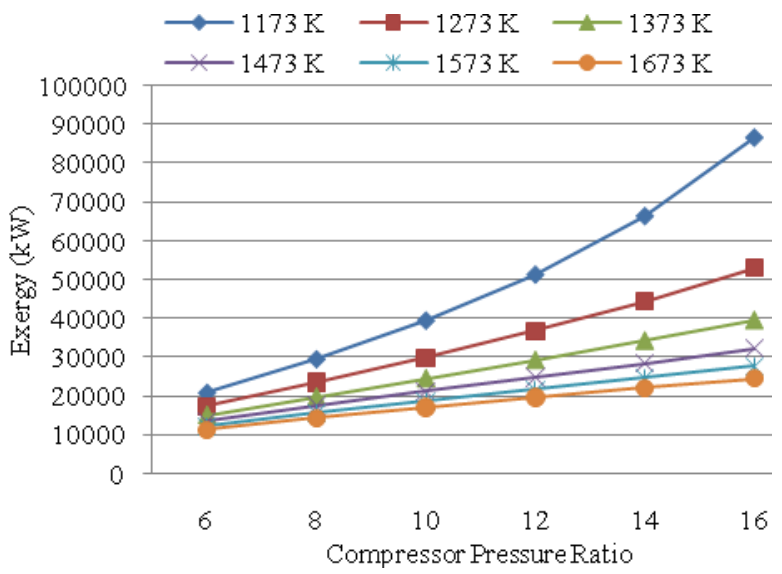

Figure 5. Graph of exergy loss in gas turbine vs $r_{p c}$ at different TIT.

Figure 5 shows the variation of exergy loss in gas turbine with variation in compressor pressure ratio and turbine inlet temperature. At low turbine inlet temperature $\left(900^{\circ} \mathrm{C}\right)$ the exergy loss in the gas turbine is higher and as the turbine inlet temperature increases $\left(1400^{\circ} \mathrm{C}\right)$ the exergy loss is minimizing rapidly. At any particular turbine inlet temperature as the compressor pressure ratio increases the exergy loss increases. The behavior of curve is linear from $1100^{\circ} \mathrm{C}$ to $1400^{\circ} \mathrm{C}$ and increases slowly rather than at 900 to $1000^{\circ} \mathrm{C}$. In gas turbine $2-7 \%$ of exergy loss is calculated.

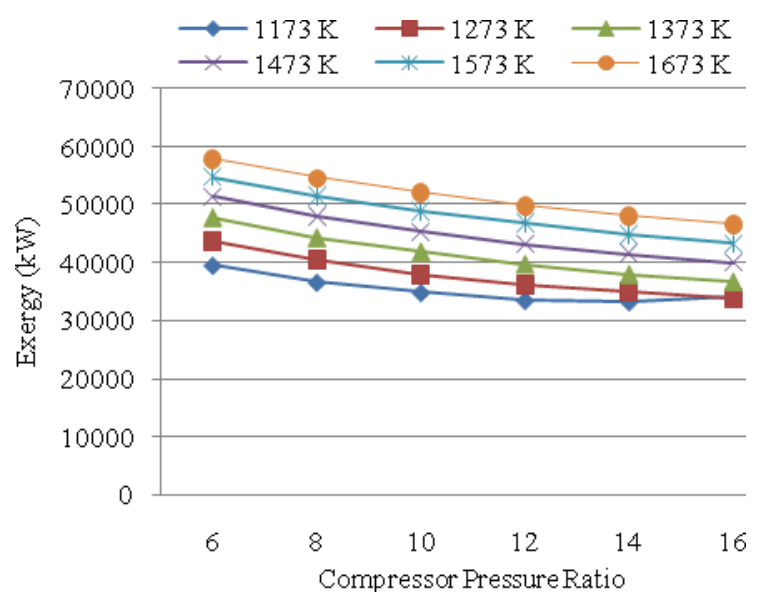

Figure 6. Graph of exergy loss in HRSG vs $r_{p c}$ at different TIT.

Figure 6 shows the variation of exergy loss in heat recovery steam generator with variation in compressor pressure ratio and turbine inlet temperature. At low turbine inlet temperature $\left(900^{\circ} \mathrm{C}\right)$ the exergy loss in the HRSG is lower and as the turbine inlet temperature increases $\left(1400^{\circ} \mathrm{C}\right)$ the exergy loss is increasing rapidly. There is similar pattern in exergy loss can be seen at temperature 1000 to $1400^{\circ} \mathrm{C}$ but at low turbine inlet temperature, the pattern is slightly different. At any particular turbine inlet temperature as the compressor pressure ratio increases the exergy loss decreases slowly. In HRSG $15 \%$ to $31 \%$ of exergy loss is calculated.

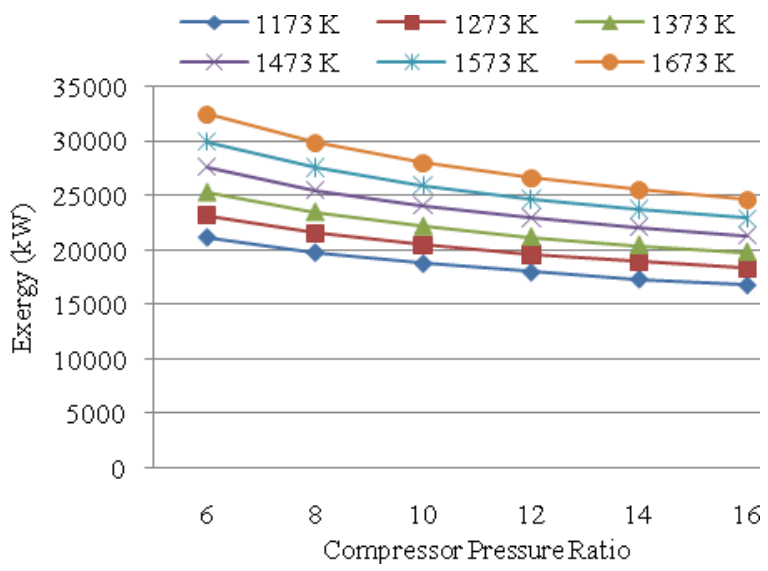

Figure 7. Graph of exergy loss in steam turbine $v s r_{p c}$ at different TIT.

Figure 7 shows the variation of exergy loss in steam turbine with variation in compressor pressure ratio and turbine inlet temperature. At low turbine inlet temperature $\left(900^{\circ} \mathrm{C}\right)$ the exergy loss in the steam turbine is lower and as the turbine inlet temperature $\left(1400^{\circ} \mathrm{C}\right)$ increases, the exergy loss is increasing rapidly. There is similar pattern in exergy loss can be seen at temperature 1000 to $1400^{\circ} \mathrm{C}$ but at low turbine inlet temperature, the pattern is slightly different. At any particular turbine inlet temperature as the compressor pressure ratio increases the exergy loss decreases slowly. In steam turbine $5 \%$ to $15 \%$ of exergy loss is calculated.

Figure 8 shows the variation of exergy loss in exhaust with variation in compressor pressure ratio and turbine inlet temperature. At low turbine inlet temperature $\left(900^{\circ} \mathrm{C}\right)$ the exergy loss in the exhaust is higher and as the turbine inlet 
temperature $\left(1400^{\circ} \mathrm{C}\right)$ increases, the exergy loss is minimizing rapidly. There is similar pattern in exergy loss can be seen at temperature 1000 to $1400^{\circ} \mathrm{C}$ but at low turbine inlet temperature, the pattern is slightly different. At any particular turbine inlet temperature as the compressor pressure ratio increases the exergy loss increases. The behavior of curve is linear from $1100^{\circ} \mathrm{C}$ to $1400^{\circ} \mathrm{C}$ and increases slowly rather than at 900 to $1000^{\circ} \mathrm{C}$. In exhaust $10-20 \%$ of exergy loss is calculated.

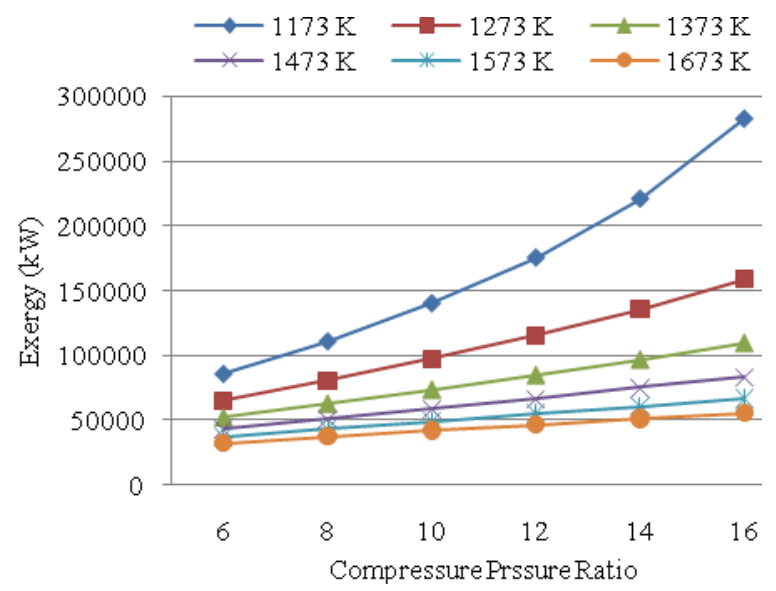

Figure 8. Graph of exergy loss in exhaust $v s r_{p c}$ at different TIT.

Figure 9 shows the percentage of exergy loss in all the components. In compressor $4-8 \%$ of exergy loss is calculated.

$\begin{array}{ll}\text { - Compressor }(8 \%) & \text { Combustion Chamber }(35 \%) \\ \text { Gas Turbine }(7 \%) & \text { - HRSG }(21 \%) \\ \text { - Steam Turbine }(12 \%) & \text { Exhaust }(17 \%)\end{array}$

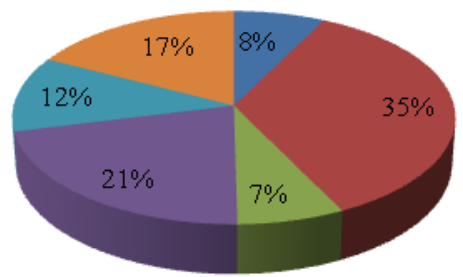

Figure 9. Pi-chart showing percentage of exergy loss in different components (Figure is in color in the on-line version of the paper).

\section{Conclusions}

On the basis of above analysis the following conclusions are made by varying the pressure ratio of compressor, turbine inlet temperature,

1) The exergy analysis gives a real picture about the losses which occurred in the different plant components.

2) Fuel consumption in the combustion chamber of gas turbine is directly dependent on desired turbine inlet temperature.

3) More exergy losses occur in the combustion chamber due to combustion irreversibility and this must be reduced with the aid of advanced in the new technology as the combustion process is necessary.
4) At lower turbine inlet temperature and higher pressure ratio the exergy losses in the components compressor, gas turbine and exhaust are higher.

5) At higher turbine inlet temperature and lower pressure ratio the exergy losses in the components combustion chamber, heat recovery steam generator and steam turbine are higher.

6) There are clear effects in the exergy losses when changing pressure ratio and turbine inlet temperature.

7) The exergy balance or second law approach presented facilitates the design and optimization of complex cycles by pinpointing and quantifying the losses.

8) The optimum turbine inlet temperature and pressure ratio should be the next focus of study for minimizing the total exergy losses in all the components.

\section{Acknowledgements}

The author is thankful to National Thermal Power Corporation (NTPC), dadri, India for permission to visit the plant site and taking valuable data for analysis. The author is also thankful to Executive Engineers of gas unit $\mathrm{Mr}$. Prashant, Mr. Vishal for their support at site.

\section{Annexure-I:}

$\mathrm{C}_{\mathrm{pa}}$ (Specific heat of air) $=1.005 \mathrm{~kJ} / \mathrm{kg} \mathrm{K}$

$\mathrm{C}_{\mathrm{pg}}($ Specific heat of gas $)=1.148 \mathrm{~kJ} / \mathrm{kg} \mathrm{K}$

$\mathrm{cv}$ (Calorific value of natural gas used as a fuel $)=42 \mathrm{MJ} / \mathrm{kg}$ $\mathrm{m}_{\mathrm{s}}($ Steam flow rate $)=162.76 \mathrm{~kg} / \mathrm{s}$

$\mathrm{P}_{1}, \mathrm{~T}_{1}$ (air to the compressor) $=1 \mathrm{bar}, 298 \mathrm{~K}$

$\mathrm{P}_{\mathrm{a}}, \mathrm{T}_{\mathrm{a}}$ (steam inlet to steam turbine $)=60 \mathrm{bar}, \mathrm{T}_{\mathrm{a}}$

$\mathrm{P}_{\mathrm{c}}($ Condenser pressure $)=0.8864 \mathrm{bar}$

$\mathrm{r}_{\mathrm{pc}}$ (Compressor Pressure Ratio) $=6$ to 16

$\mathrm{T}_{0}$ (Ambient Temperature $)=298 \mathrm{~K}$

$\mathrm{T}_{3}$ (Turbine Inlet Temperature) $=1173$ to $1673 \mathrm{~K}$

$\mathrm{T}_{\mathrm{e}}$ (Feed water temperature to the HRSG) $=170.4^{0} \mathrm{C}$

$\beta_{1}$ (Pressure drop in the combustion chamber) $=3 \%$

$\beta_{2}$ (Pressure drop of gas in the HRSG) $=5 \%$

$\gamma_{\mathrm{a}}($ Specific heat ratio of air $)=1.4$

$\gamma_{\mathrm{g}}$ (Specific heat ratio of gas $)=1.33$

$\eta_{\mathrm{c}}$ (Adiabatic efficiency of compressor) $=0.90$

$\eta_{\mathrm{GT}}($ Adiabatic efficiency of GT $)=0.90$

$\eta_{\mathrm{St}}($ Adiabatic efficiency of ST $)=0.82$

\section{Nomenclature}

$\mathrm{C}_{\mathrm{p}} \quad$ Specific Heat at constant pressure, $\mathrm{kJ} / \mathrm{kg} \mathrm{K}$

E Energy, $\mathrm{kW}$

Ex Exergy, kW

GT Gas Turbine

h Enthalpy; $\mathrm{kJ} / \mathrm{kg}$

I Irreversibility, $\mathrm{kW}$

$\mathrm{m}_{\mathrm{a}} \quad$ Mass flow rate of air in cycle, $\mathrm{kg} / \mathrm{s}$

$\mathrm{m}_{\mathrm{g}} \quad$ Mass flow rate of Gas in cycle, $\mathrm{kg} / \mathrm{s}$

P Pressure, bar

R Gas Constant, $\mathrm{kJ} / \mathrm{kg} \mathrm{mol} \mathrm{K}$

$\mathrm{r}_{\mathrm{pc}} \quad$ Compressor Pressure ratio

$\mathrm{r}_{\mathrm{pg}} \quad$ Gas Turbine Pressure ratio

s Entropy; $\mathrm{kJ} / \mathrm{kg}$

ST Steam Turbine

$\mathrm{T}_{1} \quad$ Compressor inlet temperature in GT cycle, $\mathrm{K}$

$\mathrm{T}_{2} \quad$ Compressor exit temperature in GT cycle, $\mathrm{K}$

$\mathrm{T}_{3} \quad$ Turbine inlet temperature in GT cycle, $\mathrm{K}$

$\mathrm{T}_{4} \quad$ Turbine exit temperature from GT cycle, $\mathrm{K}$

$\mathrm{T}_{5} \quad$ Pinch Point Temperature, $\mathrm{K}$

$\mathrm{T}_{6} \quad$ Stack Temperature, $\mathrm{K}$ 

Saturation Temperature, $\mathrm{K}$ Turbine inlet temperature, $\mathrm{K}$ Dryness Fraction Efficiency of Combined cycle Efficiency of gas turbine cycle Efficiency of steam turbine cycle

\section{References}

Aljundi, I.H., (2009). Energy and exergy analysis of a steam power plant in Jordan. Applied Thermal Engineering, 29, 324-328.

Bassily, A.M., (2005). Modeling, numerical optimization, and irreversibility reduction of a dual-pressure reheat combined-cycle. Applied Energy, 81, 127-151.

Bejan, A., (2002). Fundamentals of exergy analysis, entropy generation minimization, and the generation of flow architecture. Int J Energy Res, 26, 545-565.

Cerri, G. (1987). Parametric analysis of combined gassteam cycles. J. Eng. Gas Turbines Power, 109(1), 4654.

Czermak, H., \& Wansch, A. (1982). The 125 MW combined cycle plant Korneuburg; Design features, plant performance and operation experience. ASME paper $82 G T-323$.

EI-Masri, M.A., (1987). Exergy Analysis of Combined Cycles: Part 1 - Air-Cooled Brayton-Cycle.Gas Turbines. J. Eng. Gas Turbines Power, 109(2), 228-236.

Franco, A., (2011). Analysis of small size combined cycle plants based on the use of supercritical HRSG. Applied Thermal Engineering, 31, 785-794.

Heppenstall, T., (1998). Advanced gas turbine cycles for power generation: a critical review. Applied Thermal Engineering, 18, 837-846.

Horlock, J.H., (1995). Combined power plants-past, present, and future. Journal of engineering for gas turbines and power, 117(4), 608-616.

Ibrahim, T. K., Rahman, M.M, Abdalla, A.N., (2011). Optimum Gas Turbine Configuration for Improving the performance of Combined Cycle Power Plant. Procedia Engineering, 15, 4216 - 4223.
Koch, C., Cziesla, F., Tsatsaronis, G., (2007). Optimization of combined cycle power plants using evolutionary algorithms. Chemical Engineering and Processing, 46, 1151-1159.

Manfrida, G., Bosia, A. and Bindini, G., (1988). Second law analysis of combined gas/steam cycles. Proc. $23 \mathrm{rd}$ Intersociety energy conversion engineering conference, pp 391-397.

Mansouri, M.T., Ahmadi, P., Kaviri, A.G., Jaafar, M.N.M., (2012). Exergetic and economic evaluation of the effect of HRSG configurations on the performance of combined cycle power plants. Energy Conversion and Management, 58, 47-58.

Nag, P.K. and Raha, D., (1995). Thermodynamic analysis of a coal-based combined cycle power plant. Heat Recovery Systems and CHP, 15(2), 115-129.

Polyzakis, A., (1995). Industrial gas-turbine for combined cycle plant. M.Sc. thesis, Cranfield University, 1995.

Polyzakis, A.L., Koroneos, C., Xydis, G., (2008). Optimum gas turbine cycle for combined cycle power plant. Energy Conversion and Management, 49, 551-563.

Regulagadda, P., Dincer, I., Naterer, G.F., (2010). Exergy analysis of a thermal power plant with measured boiler and turbine losses. Applied Thermal Engineering, 30, 970-976.

Sanjay, (2011). Investigation of effect of variation of cycle parameters on thermodynamic performance of gassteam combined cycle. Energy, 36, 157-167.

Sieppel, C., Bereuter, R., (1960). The theory of combined steam and gas-turbine installation. Brown Boveri Review, 47, 783-799.

Srinivas, T. (2010). Thermodynamic modelling and optimization of a dual pressure reheat combined power cycle. Sadhana, 35(5), 597-608.

Wu, C., (1999). Intelligent computer-aided sensitivity analysis of multi-stage Brayton/Rankine combined cycle. Energy Conversion and Management, 40, 215232.

Wunsch, A., (1985). Highest efficiencies possible by converting gas-turbine plants into combined cycle plants. Brown Boveri Review, 10, 455-463. 